\title{
Fine-scale habitat selection of Chilean dolphins (Cephalorhynchus eutropia): interactions with aquaculture activities in southern Chiloé Island, Chile
}

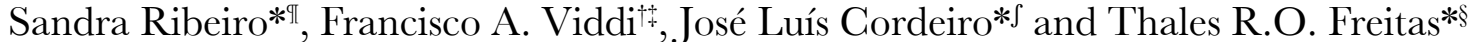 \\ *Programa de Pós-Graduação em Ecologia, Universidade Federal do Rio Grande do Sul (UFRGS), Av. Bento Gonçalves 9500, \\ Caixa Postal 15007 CEP 91540-000, Porto Alegre, RS, Brazil. ${ }^{\dagger}$ Marine Mammal Research Group, Graduate School of the \\ Environment, Macquarie University, Sydney, NSW 2109, Australia. ${ }^{\ddagger}$ Centro Ballena Azul (CBA/BWG), Carlos Anwandter 624, \\ Casa 4, Valdivia, Chile. SLaboratório de Geoprocessamento, Centro de Ecologia, UFRGS, RS, Brazil. \$Laboratório de Genética \\ Molecular, Departamento de Genética, UFRGS, RS, Brazil. "Corresponding author, e-mail: sandripes@yahoo.com
}

Fine-scale habitat selection of Chilean dolphins was studied between January and April 2002 through shorebased theodolite tracking in order to investigate the environmental and behavioural determinants of habitat use, and to evaluate the interactions between this species and aquaculture activities in Yaldad Bay, southern Chile. During 293.5 h of effort, movement and habitat selection patterns of dolphins exhibited a significantly concentrated use of only $21 \%$ of the entire study area. Correspondence analysis showed that shallow waters (5-10 m), proximity to coast and rivers were the most significant environmental parameters determining finescale dolphin distribution patterns, with foraging the most frequently observed activity. Aquaculture activities in the area were observed to affect dolphin habitat use patterns by restricting space available for biologically important dolphin behaviours.

\section{INTRODUGTION}

The Chilean dolphin, Cephalorhynchus eutropia, is the only cetacean species endemic to Chile, distributed from Valparaiso $\left(33^{\circ} \mathrm{S}\right)$ to Navarino Island, Cape Horn $\left(55^{\circ} \mathrm{S}\right)$. It is a coastal species, inhabiting sheltered bays, channels, fjords and exposed coast (Goodall, 1994). Basic knowledge about its biology and ecology are still very limited and there are no data available on abundance, population dynamics, home range size and movement patterns, a consequence of which is that its current conservation status still corresponds to Data Deficient as listed by the IUCN (IUCN, 2004).

The main concern for the conservation of Chilean dolphins is the incidental catch in local fisheries and the progressive destruction of potentially critical areas mainly due to aquaculture activities (for mussel and salmon), which have expanded rapidly in the sheltered bays, channels and fjords of southern Chile (Buschmann et al., 1996).

Since its implementation in Chilean waters in 1980, the aquaculture industry has increased more than 140-fold in its initial production, especially in the Tenth Administrative Region of Chile, which is responsible for more than $90 \%$ of the national aquaculture production (Claude et al., 2000). Given that mussels and salmon are cultivated on a massive scale, they can generate intense organic enrichment and reduce the amount of oxygen available on the sea-floor and in the water column through high bio-deposition rates (from faeces and pseudofaeces), frequent detachment of individual mussels from suspended systems and external supplementary feeding (rich in phosphorus and nitrogen) for salmon, all of which cause significant and potential impacts on the environment, such as modification of benthic community and local biodiversity (Buschmann et al., 1996; Naylor et al., 2000). Furthermore, mussel farming takes up three dimensional space in near-shore waters and can restrict animals, such as dolphins, from using the available space, reducing the extent of areas used for potentially important biological and social activities (Würsig \& Gailey, 2002; Kemper et al., 2003).

Interactions between aquaculture activities and marine mammals are generally thought to be negative (Würsig \& Gailey, 2002; Kemper et al., 2003). Marine mammals might be affected by shooting, netting, and due to the use of acoustic devices to prevent the animals approaching, area abandonment and even subsequent death might occur (Würsig \& Gailey, 2002).

The main purpose of this study is to describe habitat selection patterns of Chilean dolphins, while identifying potential environmental features responsible for fine-scale habitat use and to assess the interactions between this species and aquaculture activities in Yaldad Bay, Chiloé Island.

\section{MATERIALS AND METHODS Study area}

Yaldad Bay is located in southern Chiloé Island, Chile $\left(43^{\circ} 08^{\prime} \mathrm{S} 73^{\circ} 44^{\prime} \mathrm{W}\right)$ (Figure 1) and has an area of $\sim 22 \mathrm{~km}^{2}$. The bay's average depth is about $13.4 \mathrm{~m}$, with a maximum of $32 \mathrm{~m}$. Average slope is $2.3 \%$ and the maximum $12 \%$. The tidal cycle is semidiurnal, with amplitudes ranging from 3 to $5 \mathrm{~m}$. The bay receives freshwater input from four rivers $(\sim 25 \mathrm{~m}$ wide) and 17 streams (Figure 1$)$. An extensive area 


\section{Yaldad Bay}
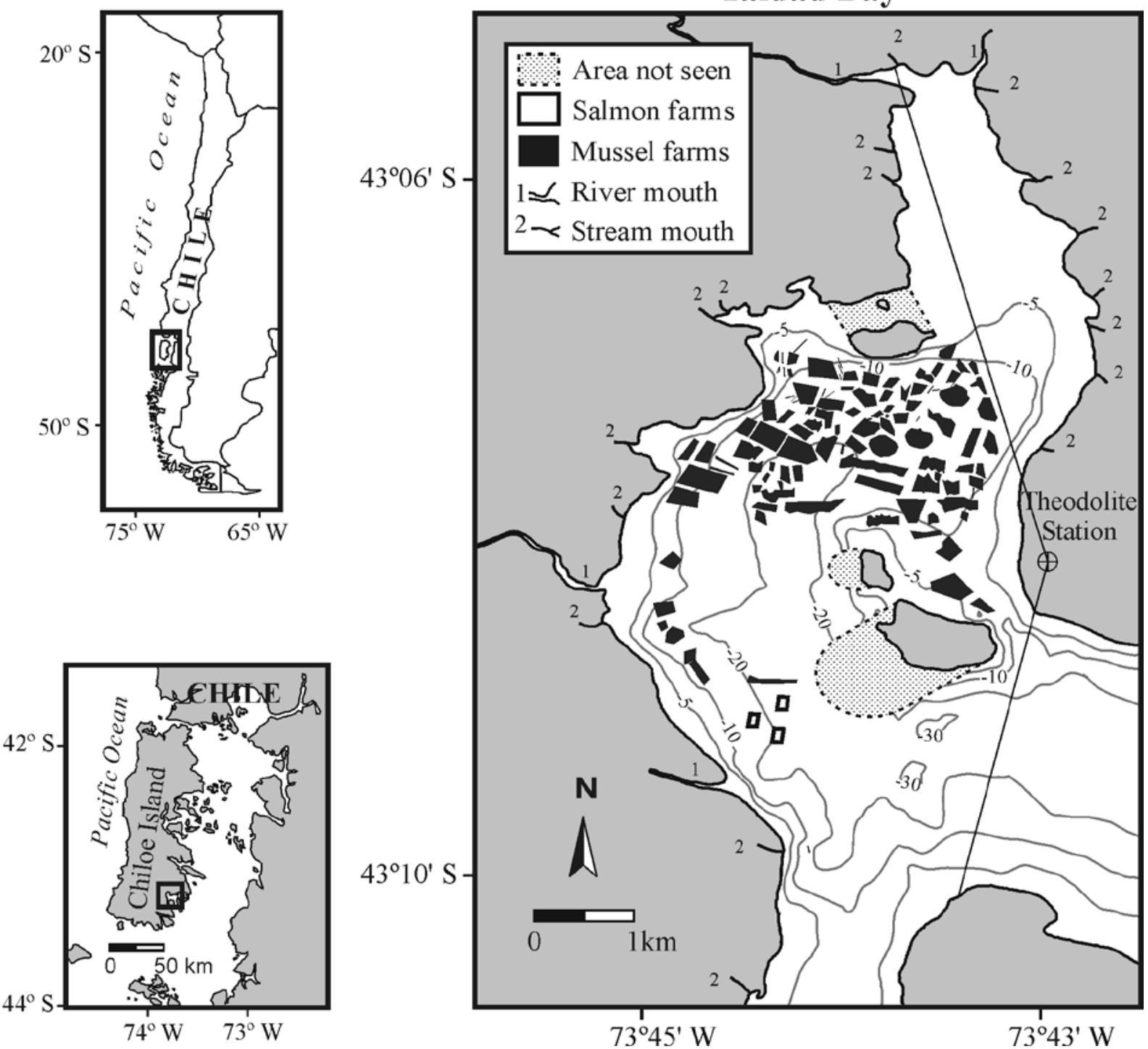

Figure 1. Study area in Yaldad bay, southern Chile. Theodolite station $(\oplus)$ and field of view $(-)$.

of the bay is used for cultivating the mussel Mytilus edulis chilensis, which has progressively extended since the late 1980s. Salmon farming is also carried out in the bay to grow Atlantic salmon, Salmo salar.

\section{Data collection}

Between January and April 2002, land-based observations were performed from a fixed vantage point $102.78 \mathrm{~m}$ above sea level (Figure 1). The geographical positions of dolphins were determined using a digital theodolite 'Pentax ETH10D' (precision \pm 10 " of arc and magnification $30 \times$ ), which measures horizontal and vertical angles that can then be converted into x/y map coordinates (see Würsig et al., 1991 for details). For this particular study, this procedure was performed by using the software PYTHAGORAS ${ }^{\odot}$ (G. Gailey, Texas A\&M University).

The precision of the theodolite fixes is proportional to the instrument's elevation above sea level and inversely proportional to the distance of the acquired fix. Furthermore, the greatest source of position error is inaccuracy in theodolite height (Würsig et al., 1991). Considering the tide amplitude in the study area, it was necessary to continuously correct the theodolite height in relation to sea level during the observation period. By using a Correction Tide Table from the Chilean Navy available for the region, the tide height was calculated at ten-min intervals. We estimated that a $50 \mathrm{~cm}$ error in theodolite height (the maximum believed possible in this study) would cause a position error of approximately $15 \mathrm{~m}$ at a range of $3000 \mathrm{~m}$ (Würsig et al., 1991). This error is considered not to have affected the results of this study.

Two to three observers, using binoculars $(10 \times 50)$ and a tripod-mounted spotting scope with $60 \times$ magnification, scanned the study area to locate a dolphin group, which was then tracked throughout the entire observation period until it was lost (group follow protocol, after Mann, 1999a). A group of dolphins was defined as any aggregation of one or more dolphins (including all age-classes) observed close to each other within $100 \mathrm{~m}$, in apparent association and often engaged in similar activities.

Theodolite fixes were taken at the centre of the dolphin group approximately every 60 seconds. In addition, every fix point included information on time (hour, minute and 
Table 1. Variables used in the correspondence analysis. Intensity of habitat use of Cephalorhynchus eutropia was classified into four categories (according to dolphin permanence time in each cell); and environmental variables were classified into 25 categories identified with a numerical code.

\begin{tabular}{|c|c|c|}
\hline Variable & Category & \\
\hline Intensity of habitat use (min.) & $\begin{array}{c}0 \\
1-10 \\
11-25 \\
\geq 25\end{array}$ & $\begin{array}{c}\text { Absent } \\
\text { Little } \\
\text { Intermediate } \\
\text { High }\end{array}$ \\
\hline Environmental variables & & Numerical code \\
\hline Distance to coast (m) & $\begin{array}{c}0-250 \\
251-500 \\
501-1000 \\
\geq 1000\end{array}$ & $\begin{array}{l}1 \\
2 \\
3 \\
4\end{array}$ \\
\hline $\operatorname{Depth}(\mathrm{m})$ & $\begin{array}{c}0-5 \\
6-10 \\
11-15 \\
16-20 \\
\geq 20\end{array}$ & $\begin{array}{l}5 \\
6 \\
7 \\
8 \\
9\end{array}$ \\
\hline Declivity (\%) & $\begin{array}{c}0 \\
1-5 \\
\geq 5\end{array}$ & $\begin{array}{l}10 \\
11 \\
12\end{array}$ \\
\hline Distance to rivers (m) & $\begin{array}{c}0-500 \\
501-1000 \\
\geq 1000\end{array}$ & $\begin{array}{l}13 \\
14 \\
15\end{array}$ \\
\hline Distance to streams (m) & $\begin{array}{c}0-350 \\
351-700 \\
\geq 700\end{array}$ & $\begin{array}{l}16 \\
17 \\
18\end{array}$ \\
\hline Distance to salmon farms (m) & $\begin{array}{c}0-250 \\
251-500 \\
\geq 500\end{array}$ & $\begin{array}{l}19 \\
20 \\
21\end{array}$ \\
\hline Mussel farm coverage (\%) & $\begin{array}{c}0 \\
1-30 \\
31-60 \\
\geq 60\end{array}$ & $\begin{array}{l}22 \\
23 \\
24 \\
25\end{array}$ \\
\hline
\end{tabular}

seconds), and activity pattern following focal group sampling (Mann, 1999a). If a group was not sighted for five minutes, searching for a new group was started. This was done to ensure that each track was continuous.

The activities (behavioural states) considered were defined as follows:

-Feeding: cooperative hunting of fish schools. Dolphins were seen chasing fish; making circles; having a parallel swimming formation, with fast, directional and synchronized movements; fish leaping out of the water; and even dolphins with fish in their mouths. Dolphins were frequently observed in association with marine birds, such as South American terns Sterna hirundinacea.

-Foraging: repeated unsynchronized dives in different directions in a determined location, probably representing scanning and searching for food or possibly benthic feeding.

-Resting: very slow movements or staying still at the surface.

-Socializing: inter-individual interactions within a group, in frequent physical contact, with frequent vigorous movements and aerial behaviours such as leaping and breaching. Sexual and aggressive behaviours were also included within this category.

-Travelling: directional and persistent movement at speed.

Observation effort and tracking sessions varied and were limited to favourable environmental conditions. When possible, observations started at $0800 \mathrm{~h}$ through to $1900 \mathrm{~h}$, and were restricted to good visibility conditions, no rain and sea states of Beaufort 2 or less.

In order to evaluate the habitat use patterns in relation to aquaculture activities in the bay, fixes from the vertex of each structure (such as salmon cages and mussel long lines) were obtained with the theodolite. These fixes were then plotted and mapped resulting in the spatial distribution of polygons of areas occupied by mussel and salmon farms (Figure 1). The unobservable areas obscured by islands were estimated by taking fixes of the treetops on the islands, which represented geographical positions on the water surface, delineating the unseen area (Figure 1).

Considering only that area within the field of view and excluding the zone obscured by the islands, $16 \mathrm{~km}^{2}$ were effectively searched, which represents $73 \%$ of the entire bay area.

\section{Spatial analysis}

By performing a spatial analysis with Geographic Information Systems (IDRISI 3.2 ${ }^{\circledR}$ ), independent variables such as depth, slope, distance to the coast, rivers, streams (small rivers) and aquaculture structures were extracted for correlation of dolphin habitat use patterns. Thematic maps were constructed for each of these variables in a raster format of $1 \times 1 \mathrm{~m}$ cell resolution. Water depth was estimated from bathymetry maps (Winter et al., 1982) and complemented with bathymetry profiles obtained using a handheld Hondex Depth Sounder.

The entire area was divided into $100 \times 100 \mathrm{~m}$ cells for further analysis (1589 cells in total). These were then overlapped with each of the thematic variable maps separately to obtain a variable average value for each cell, which was considered the sample unit for further statistical analysis.

The intensity of habitat use by dolphins (dependent variable) was obtained by plotting the position of all groups sighted and overlaying this with the cell-gridded base map. Since each position represented a short time interval, it was possible to obtain the total time dolphins spent in a particular cell. The intensity of habitat use in each cell was also recorded for each of the activities observed.

Mussel farms with suspended growth lines cover large areas that were estimated by transforming their vectorial polygons into a raster format of $1 \times 1 \mathrm{~m}$ cell resolution. Crossing this map with the $100 \times 100 \mathrm{~m}$ cell-gridded base map, the number of pixels $(1 \times 1 \mathrm{~m})$ was obtained with mussel farming in a respective cell and hence mussel cover percentage for each cell was assessed.

\section{Habitat selection analysis}

To determine whether or not Chilean dolphins used the bay proportionally, a one-sided Kolmogorov-Smirnov goodness-of-fit test was used. Chilean dolphin habitat use was assessed by analysing the intensity of use in relation to 


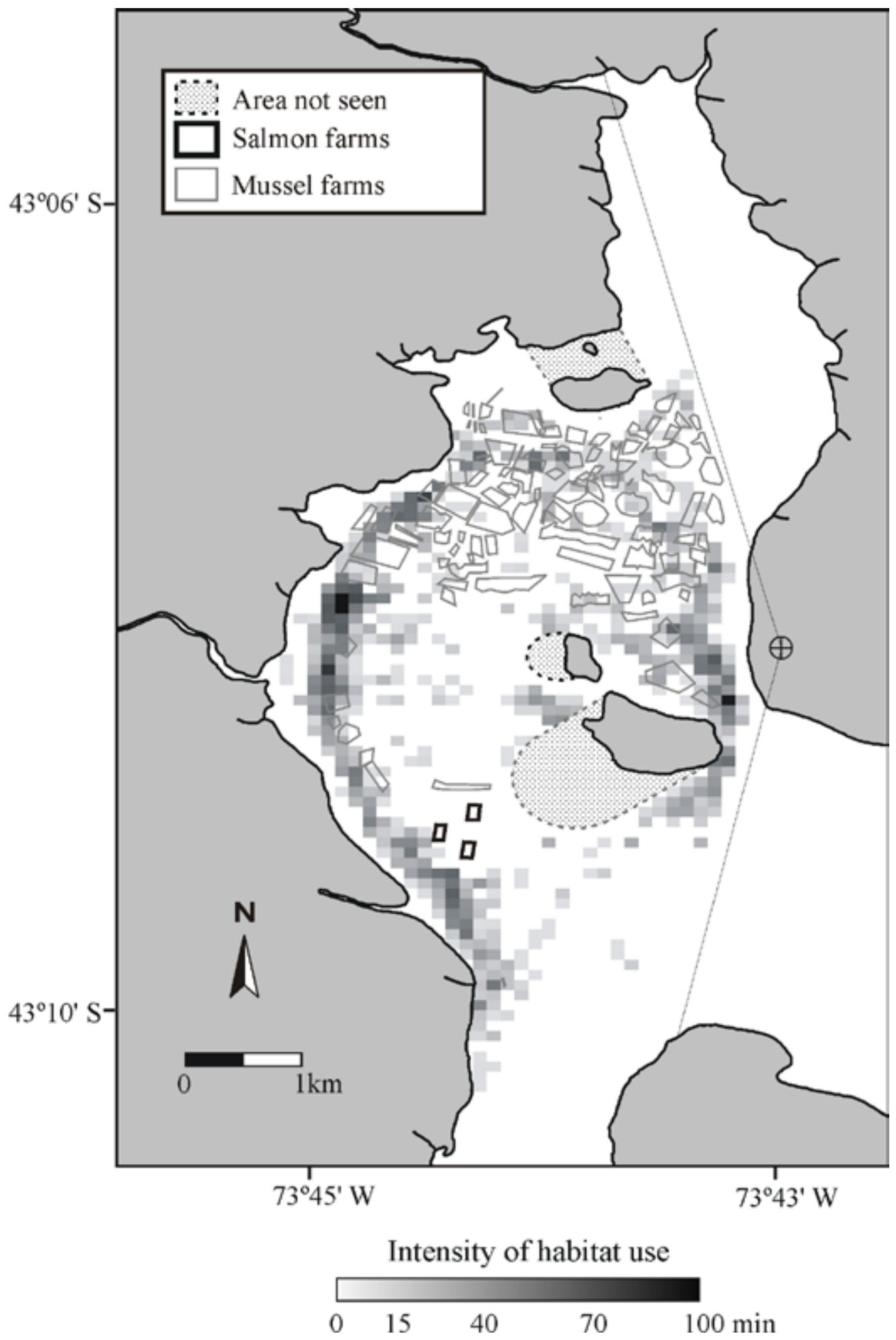

Figure 2. Intensity of habitat use by Chilean dolphins in Yaldad Bay.

the environmental variables for each cell. A correspondence analysis was performed (using SPSS v. 8.0) to identify those environmental variables associated with the sites selected by dolphins. All environmental variables and intensity of habitat use by dolphins were first categorized. Time spent by dolphins in each cell was classified into four categories of intensity of habitat use: absent, little, intermediate and high use. Environmental variables were classified into a total of 25 categories (Table 1). Residual analysis was later performed to evaluate any significant relationship among variable categories.

\section{Activity patterns and habitat use}

To determine whether time spent in each of the behavioural states was distributed uniformly, or whether there was a specific activity performed more frequently than others, a 


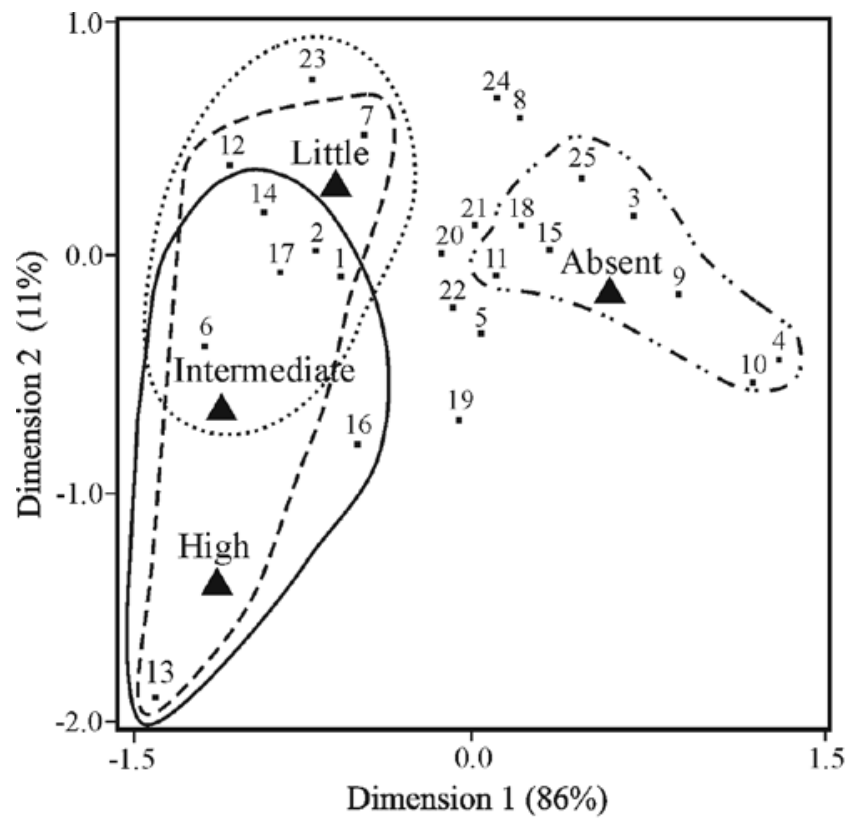

- Environmental variables $\boldsymbol{\Delta}$ Intensity of use -..- Absent ....... Little ---Interm. - High

Figure 3. Correspondence analysis between environmental variables represented by numerical codes (Table 1) and intensity of use by Chilean dolphins. Oval lines distinguish significant associations obtained by adjusted residuals analysis $(P<0.05)$.

chi-squared goodness-of-fit test was performed, based on the frequency of occurrence of each activity in relation to the total observation time of dolphins.

Canonical correlations analysis (using STATISTICA v. 5) was used to identify associations between behavioural states and environmental variables. The significance for the canonical correlation between the two variable sets as well as for the variates was estimated through $\chi^{2}$-testing. The five behavioural states were the dependent (or response) variables and depth, mussel coverage, distance to rivers, distance to streams and slope were the environmental factors included as independent (or predictor) variables. Distance to the coast and distance to salmon farms were not considered to avoid problems of multicolinearity since these variables presented a correlation greater than $50 \%$ with other variables. The interpretation of canonical correlation is made by analysing the magnitude and direction of a standardized coefficient, the canonical weight, which comes from the significant variates. Although there is no interpreting coefficient limit defined, in this study a minimum of 0.2 was considered as a rationale.

To evaluate whether aquaculture structures influenced dolphin activities, three types of zone were established: (1) zone under direct mussel farming influence, which corresponded to areas with mussel coverage (polygons and lines and areas among these). This zone covered approximately $30 \%$ of the bay area; (2) zone under direct salmon farming influence, which corresponded to the areas within a radius of $250 \mathrm{~m}$ around salmon cages; and (3) free zone, which were the areas free of aquaculture structures. A $\chi^{2}$-test for contingency table and adjusted residual analysis were carried out (SPSS v. 8.0) to detect any significant association between activity patterns and the established zones.

The same statistical tests were performed to identify any relationship between tidal phases and behavioural states. For each theodolite reading, the tidal phase was registered in correspondence to the time of observation. Four tidal phases were considered: high tide, low tide, ebb tide and rising tide. For low and high tides, it was considered the time interval between an hour before and an hour after the time listed in the tidal tables. Rising and ebb tides corresponded to the intervals between low and high tide (as defined above), and high and low tide, respectively.

\section{RESULTS}

A total of 293.5 effort hours were accomplished in $51 \mathrm{~d}$ during a four-month study period. Dolphins were observed for $67.4 \mathrm{~h}$ (23\% of effort) and a total of 3659 theodolite readings of 192 groups were obtained. The mean interval time between readings was $1.1 \mathrm{~min}(\mathrm{SD}= \pm 0.65)$ and the mean duration of group follows was $21 \mathrm{~min}$, varying from 1 to 163 mins. The median group size was five individuals (lower quartile $=4$ and upper quartile $=7$ ), and ranged between one and 25 animals.

Observation effort was similar among months (analysis of variance ANOVA, $F=1.56, \mathrm{df}=3, P=0.21$ ). However, there was a significant difference in the observation rate among months (ANOVA, $F=3.45$, $\mathrm{df}=3, P=0.02$ ), with a gradual decrease throughout the period. Dolphin occurrence was significantly higher during January and February (summer) than during March and April (autumn) ( $t$-test, $t=3.14$, $P=0.003)$.

\section{Habitat selection}

Chilean dolphins did not use Yaldad Bay uniformly; they significantly preferred a limited area composed of 333 cells $\left(\mathrm{K}-\mathrm{S} \mathrm{D}_{\max }=0.707 \mathrm{P}<0.001\right)$. This area represented only $21 \%$ of the total study area and corresponded to a narrow stretch of coastline where dolphins were observed $91 \%$ of the time (Figure 2).

The association between the intensity of habitat use and environmental variables (correspondence analysis) showed that there was no variable in common for used and nonused areas by dolphins (Figure 3), suggesting that dolphins seem to select specific environmental features.

For those used areas (Figure 3), a gradient in the categories selected (from high to low intensity) was observed, with some of the variables in common for areas with little, intermediate and high use by dolphins. Areas close to the coast (within 500 $\mathrm{m}$, categories 1 and 2, see Table 1), with depths of 5-10 m (category 6) and intermediate distance to rivers and streams (categories 14 and 17, respectively), were the environmental characteristics selected by dolphins, independent of intensity of use. Areas with depth of 10-15 m (category 7) and sites with slope greater than 5\% (category 12) were used with little or intermediate intensity, while close proximity to rivers and streams (categories 13 and 16, respectively) constituted the dominant environmental features, which characterized areas of intense use by dolphins. Animals were absent from sites more than $500 \mathrm{~m}$ away from shore (categories 3 and 4), 


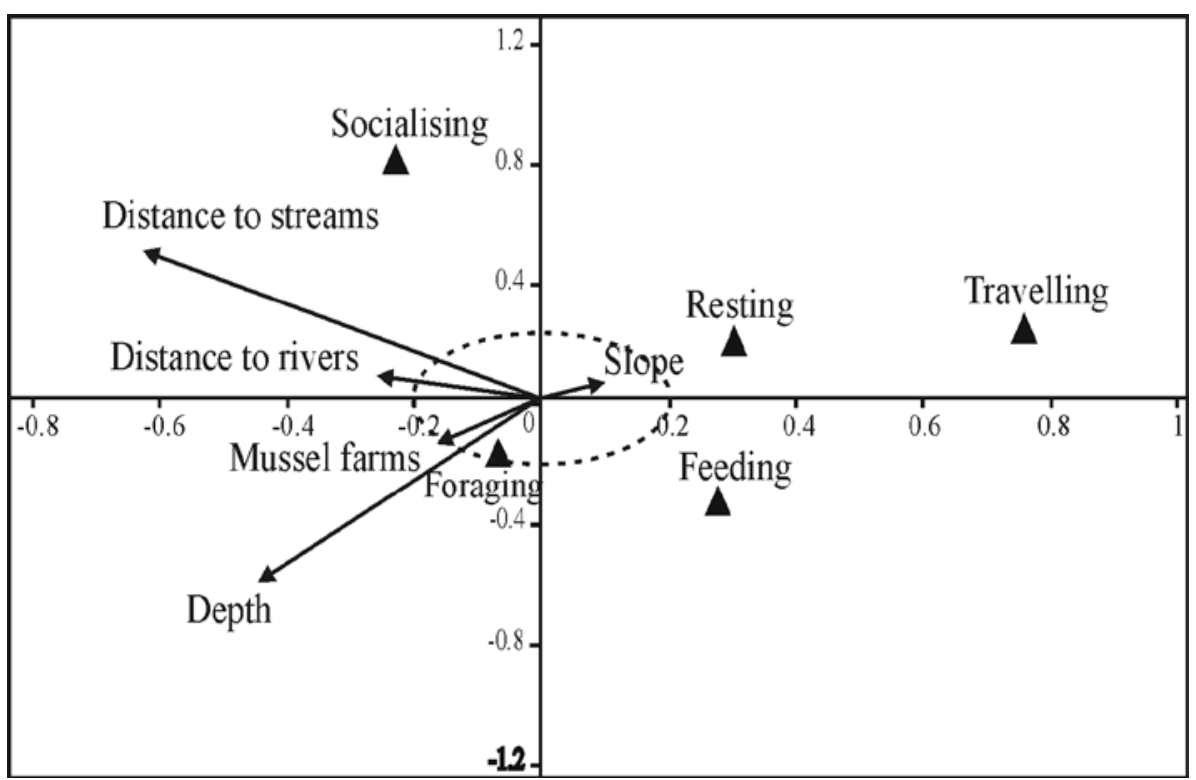

Figure 4. Canonical correlation analysis between activity patterns (behavioural states) of Chilean dolphins $(\boldsymbol{\Lambda})$ and environmental variables (arrows). Arrows indicate direction and magnitude of the weights along a gradient and their extent is proportional to their contribution to the correlation. The closer and more directional the arrow points towards the black triangles, the more positively correlated are the two variables. The central dotted-line oval sets the limits of minimum coefficient for interpretation (0.2). The variables slope, mussel coverage and foraging were not considered since they were below 0.2 .
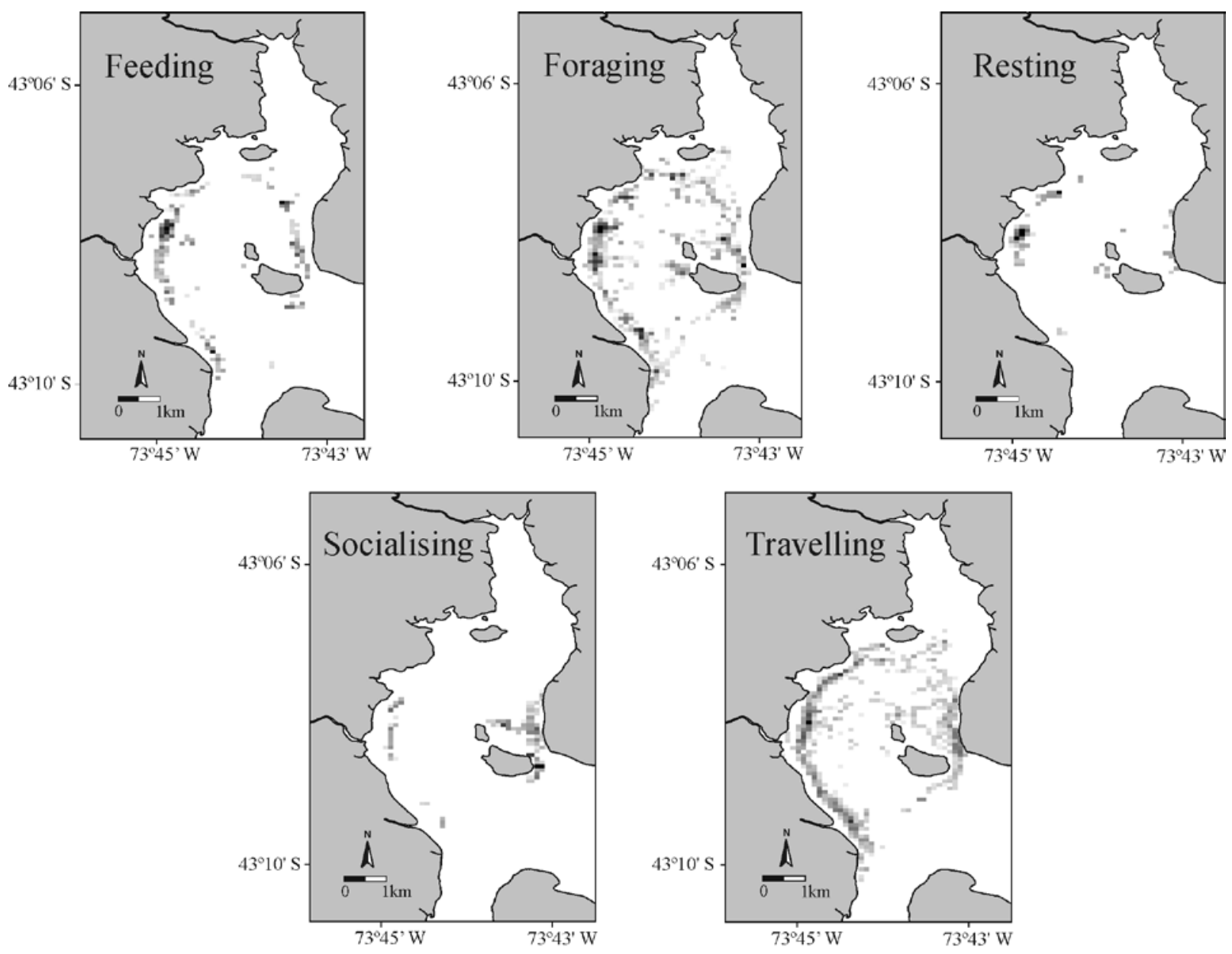

\section{Intensity of habitat use}

$\begin{array}{lllll}0 & 15 & 40 & 70 & 100 \mathrm{~min}\end{array}$

Figure 5. Maps of the intensity of habitat use for each activity pattern performed by Chilean dolphins in Yaldad Bay. 


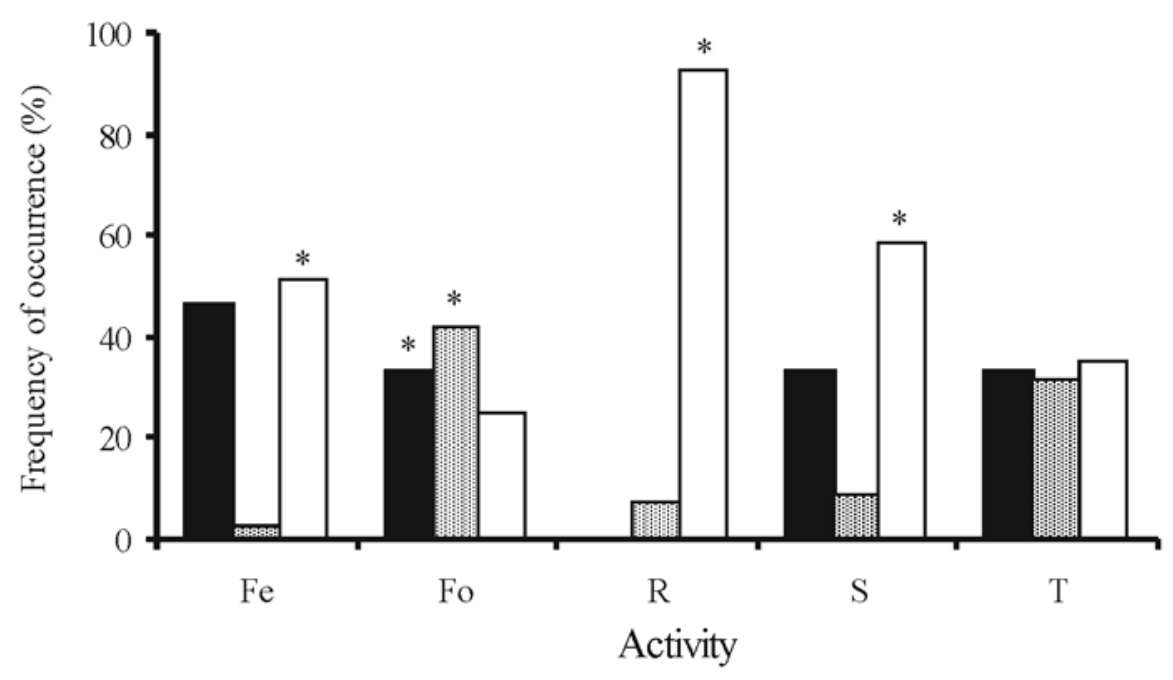

Mussel farms

國 Salmon farms

$\square$ Free areas

Figure 6. Frequency of occurrence of activity patterns (behavioural states) of Chilean dolphins: feeding (Fe), foraging (Fo), resting (R), socializing $(\mathrm{S})$ and travelling $(\mathrm{T})$ in the areas covered by mussel and salmon farming and aquaculture-free areas in Yaldad Bay. $\left({ }^{*}\right)$ indicates significant associations (adjusted residuals analysis, $P<0.05)$.

with depths greater than $20 \mathrm{~m}$ (category 9), without slope (category 10), more than $1000 \mathrm{~m}$ away from rivers (category 15) and more than $700 \mathrm{~m}$ away from streams (category 18). Hence, these were the environmental conditions not preferred by dolphins.

\section{Interactions with aquaculture}

No significant association was identified between areas of intense dolphin habitat use and distance to salmon farms. Nevertheless, according to Figure 3, the distance of up to $250 \mathrm{~m}$ to a salmon farm (category 19) is located between absent and medium habitat use categories, indicating that dolphins sometimes use areas next to salmon farms. In relation to mussel farms, dolphins used those areas with low mussel coverage (up to $30 \%$, category 23 ) with little intensity, whereas dolphins were absent in areas of high coverage (more than 60\%, category 25), (Figure 3). These results suggest that high mussel coverage restricts space available for dolphins. This statement would be arguable if areas with more than $60 \%$ of mussel coverage coincided with those sites with greater depths and distance from shore (variables not selected by dolphins-Figure 3). If this were the case, dolphins might be absent from these areas not because of mussel coverage, but rather for environmental feature selection. However, the correlation level between mussel coverage and distance to the coast and depth was very low $\left(\mathrm{r}_{\mathrm{s} \text { (mussel/deph })}=0.08\right.$ and $\left.\mathrm{r}_{\mathrm{s} \text { (mussel/dcoast) }}=0.11\right)$ indicating that cells with greater mussel coverage are not necessarily in deeper waters or further away from the coast. There was an overlap as large as $32.4 \%$ between mussel coverage (including all categories of mussel coverage) and the depth range most utilized by dolphins $(5-10 \mathrm{~m})$. Considering that dolphins only used areas with little mussel coverage, about $15.3 \%$ of the close-to-shore area was not available to them due to high-density mussel farming (over 30\% coverage).

\section{Activity patterns and habitat use}

The frequencies of occurrence of the five activity patterns (behavioural states) were not distributed uniformly $\left(\chi^{2}=42.7\right.$, $\mathrm{df}=4, P<0.001)$. Foraging was the activity most frequently observed (44.4\%) and if combined with feeding (9\%), more than half of the time (53.4\%) dolphins were engaged in activities related to food acquisition. Travelling was the second most frequently observed activity (34.1\%), followed by resting and socializing $(6.7 \%$ and $5.8 \%$, respectively).

Activity patterns were significantly correlated with environmental variables (canonical correlation analysis: $\left.\chi^{2}=117.5, \quad \mathrm{df}=25, \quad P<0.001\right)$. The canonical correlation coefficient $\left(\mathrm{r}_{\mathrm{c}}\right)$ obtained was 0.4 , indicating a variance overlap of $16 \%\left(\mathrm{r}_{\mathrm{c}}{ }^{2}\right)$ between the two sets of variables. The redundancy index for the independent and dependent variables was $8.03 \%$ and $7.75 \%$, respectively.

The magnitude and direction of weights from the two first variates which contributed to the significant canonical correlation between the two variable sets are shown in Figure 4. Feeding was more associated with areas close to inflow of rivers and streams, whereas resting and travelling were related to shallow waters (negative correlation-Figures $4 \& 5$ ). Socializing occurred regularly in deeper waters and further away from rivers and streams (Figures 4 \& 5). Despite the significant correlation between these two sets of variables, the conclusions derived from the interpretation of these results must be made with caution. The low redundancy index value indicates that the results are based on a small proportion of data variance between the sets of variables. Thus, it is not possible to conclude that an evident pattern of dependence between behaviour state and specific environmental variables exists. The canonical correlation significance would only be suggesting an association tendency.

A significant relationship was identified between activity patterns and the areas with suspended mussel growth lines, 


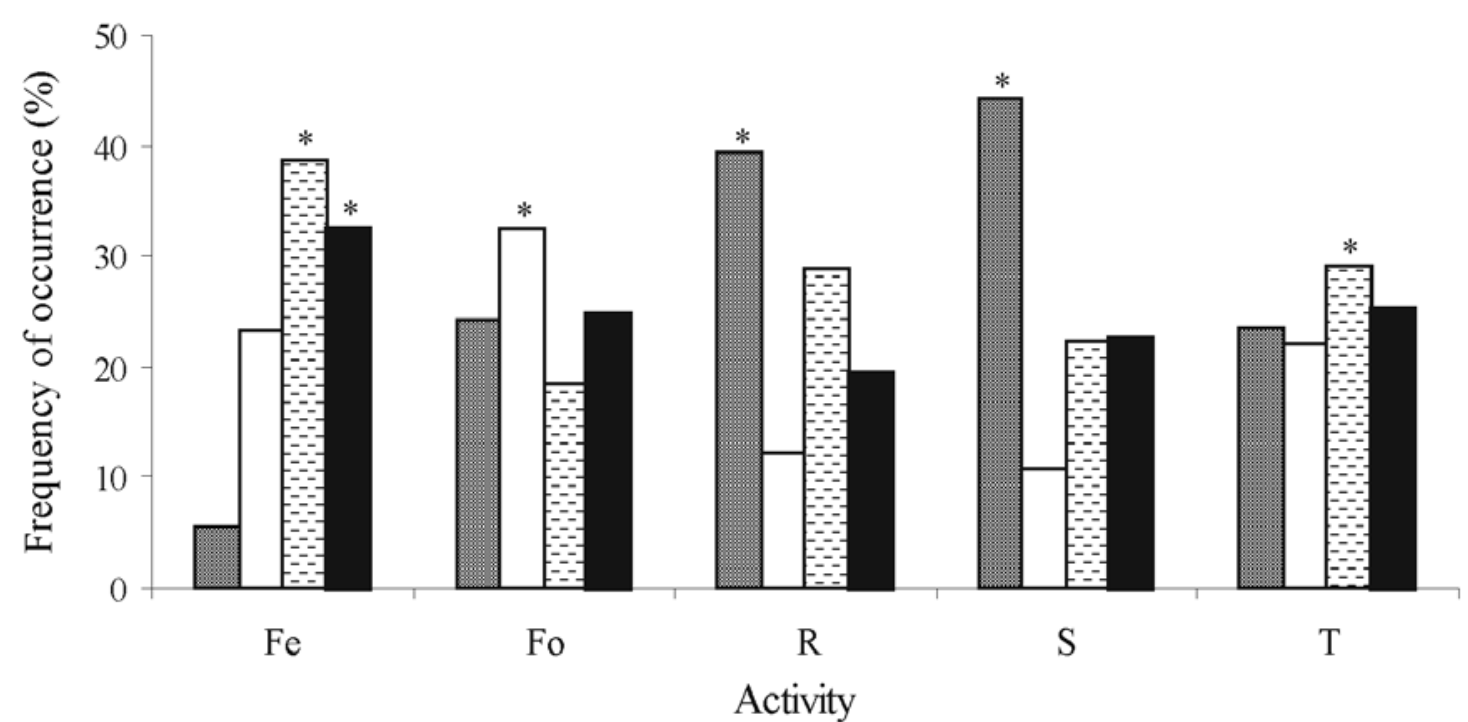

Low tide $\quad \square$ Rising tide $\quad$ OH High tide $\quad$ Ebb tide

Figure 7. Frequency of occurrence of activity patterns (behavioural states) of Chilean dolphins: feeding ( $\mathrm{Fe}$ ), foraging ( $\mathrm{Fo})$, resting (R), socializing $(\mathrm{S})$ and travelling $(\mathrm{T})$ in relation to tidal phases. $\left({ }^{*}\right)$ indicates significant associations (adjusted residuals analysis, $\left.P<0.05\right)$.

salmon cages and absence of aquaculture structures $\left(\chi^{2}=141\right.$, $\mathrm{df}=8, P<0.001)$. In areas free of aquaculture activities, dolphins were mainly observed feeding, socializing and resting (Figure 6), whereas areas occupied with aquaculture structures (both salmon and mussel farms) were more associated with foraging. Travelling was not related to any area in particular.

Dolphins' activities were also related to tidal cycles $\left(\chi^{2}=262.02, \quad \mathrm{df}=12, \quad P<0.001\right) \quad($ Figure 7$)$. Feeding was significantly associated with high and ebb tides, whereas foraging was observed more frequently during rising tide. Although resting was associated with high tide, this activity occurred mostly during low tide, just as socializing did. Even though travelling occurred with similar frequency during all tidal phases, there was a significant association with high tide (Figure 7).

\section{DISGUSSION \\ Habitat selection and use}

The unequal use of available habitat, concentrated close to shore (within $500 \mathrm{~m}$ ), showed that Chilean dolphins presented a fine-scale pattern of habitat selection. Distance to the coast, depth and distance to rivers and streams were the main environmental variables associated with the smallscale presence of dolphins in Yaldad Bay. These variables, however, were not selected with the same intensity, but rather followed a preference gradient, which represented a function of depth and principally of distance to the inflow of rivers and streams. Although dolphins selected depths between 5 and $15 \mathrm{~m}$, there was a preference for the 5-10 m depth interval, and within this interval, areas close to rivers were the most intensively used.

The results of this study are consistent with observations in other areas and at greater spatial scales. Heinrich (2001) reported that $92 \%$ of dolphin groups were sighted within $500 \mathrm{~m}$ from shore and at an average depth of $12.8 \mathrm{~m}$. Similarly, Chilean dolphins in the fjords have been found at depths ranging from 3 to $10 \mathrm{~m}$ (F.A. Viddi, personal communication). Although the information available on the ecology of the Chilean dolphin is still insufficient, the association with shallow waters appears to be typical for this species (Goodall, 1994), as well as for other species of the genus Cephalorhynchus such as Commerson's dolphin, $C$. commersonï (Lescrauwaet et al., 2000) and Hector's dolphin, $C$. hectori (Bejder \& Dawson, 2000). Bräger et al. (2003) showed that Hector's dolphin habitat preference can be explained significantly by water depth, water clarity and sea surface temperature. Nevertheless, they also suggested that these variables are not likely to be the only factors determining habitat selection in Hector's dolphin. Other parameters such as spatial differences in environmental structure, e.g. river mouths, underwater reefs and prominent headlands, appear to contribute to fine-scale variability in site usage and distribution (Bräger et al., 2003).

Most studies on coastal dolphins propose that habitat selection patterns occur principally as a function to distribution, movement and abundance of their prey species and secondly to refuges from predators (Stevick et al., 2002). Chilean dolphins in Yaldad Bay spent more than half of their time $(53.4 \%$ ) being involved in food-related activities (feeding and foraging), which were patchily distributed (Figure 5).

On the other hand, travelling (the second most-frequent activity observed, 34.1\%) occurred more homogeneously within the area of high use (Figure 5). Due to the low values of socializing and resting, it is possible to suggest that travelling took place directly associated with foraging and feeding, perhaps representing a route between food patches. The association between travelling and feeding has been 
widely reported in cetaceans, in which animals move rapidly over areas poor in resources and stay longer periods in rich feeding grounds (Karczmarski et al., 2000). The greater the level of food predictability, the more evident will be this movement pattern (Stevick et al., 2002).

Proximity to rivers and streams was the main factor determining habitat selection and was mostly correlated with feeding. However, in addition to the fluvial influence, which worked on a spatial scale, tidal phases worked on a temporal scale, in which feeding was principally associated with high tide. It is widely known that availability of prey is not constant over the tidal cycle. On the contrary, there are periods in which prey is more active (Stevick et al., 2002). The relationship between rivers and specific tidal phases can produce fine-scale oceanographic phenomena such as tidal fronts, which are of great importance to local fauna, especially as foraging areas for predators (Mann \& Lazier, 1991). These phenomena commonly occur in estuaries and bays with large tidal amplitudes. Stevick et al. (2002) suggested that there might be a correlation between tidal fronts and dolphins' prey. Winter et al. (1982) proposed a circulation model in Yaldad Bay, in which tidal fronts would be produced and evolve stronger during high tide and would weaken during low tide.

\section{Interactions with aquaculture activities}

The presence of salmon farms did not seem to influence or alter movement patterns and habitat use of Chilean dolphins directly. Animals were neither attracted nor tried to avoid salmon farm structures, since there was no significant association between areas close to the farms and the intensity of habitat use (absence, little, intermediate or high). However, it has been reported that salmon farms could act as an attractive element for dolphins (Würsig \& Gailey, 2002; Kemper et al., 2003), possibly due to a greater abundance of native fish that might be attracted to a salmon food surplus (Kemper et al., 2003). In Yaldad Bay, two aspects might have caused dolphin indifference towards salmon farm cages: native fish are either not attracted by salmon food surplus, or if attracted, fish species might not be a part of the Chilean dolphin diet. The lack of direct interference on habitat use patterns and movements of dolphins could also be explained in part by the fact that salmon farm cages are located outside the dolphin's preferred habitat (i.e. distant to coast and in depths greater than $15 \mathrm{~m}$ ). In the fjords of southern Chile, salmon farm structures are commonly close to the shore, and there Chilean dolphins have been observed avoiding farm cages (F.A. Viddi, personal communication). Although not yet known from Yaldad Bay, there are records of dolphin deaths in 'anti-sealion' nets in other parts of Chiloé Island and evidence of direct killing of dolphins to prevent close approaches to salmon farms (Claude et al., 2000; Kemper et al., 2003).

Although salmon farms might not seem to influence Chilean dolphin habitat use directly, their indirect negative impacts on the marine environment represent a potential threat to aquatic fauna and thus could be affecting dolphin food availability, either due to pollution or potential competition of escaped more aggressive salmon with native fish (Claude et al., 2000; Naylor et al., 2000).
Contrary to salmon farms, mussel farming appeared to directly influence Chilean dolphin habitat use and movement patterns. Dolphins used those cells with slight mussel coverage (1-30\%) with little intensity and appeared to avoid cells with over $60 \%$ mussel coverage. This pattern might indicate that Chilean dolphins only use the margins of the numerous mussel growth lines between buoys.

Although Würsig \& Gailey (2002) pointed out that mussel farms are not commonly attracting-points to cetaceans due to great amounts of lines and buoys that would make it difficult or even impossible to capture prey efficiently, the fauna associated with the floating mussel farming system might transform them into reefs, which could eventually attract dolphins (Kemper et al., 2003). Considering that foraging was the main activity observed in Chilean dolphins close to mussel farming lines, it could possibly imply that the animals might be finding food opportunistically.

One of the main negative impacts on coastal cetaceans caused by mussel farming is the loss of space (Würsig \& Gailey, 2002). In New Zealand, mussel farming is now set up in areas where dusky, Lagenorhynchus obscurus, bottlenose, Tursiops truncatus, and Hector's dolphins once used to feed, reproduce and rest (Würsig \& Gailey, 2002). Mann (1999b) pointed out that the presence of oyster farming in Shark Bay, Australia, had an effect on movement patterns of Indian Ocean bottlenose dolphins, T. aduncus. Mothers and calves were excluded from areas after the setting up of oyster farms, however, dolphins returned after the farms were removed (Mann \& Janik, 1999).

The absence of Chilean dolphins in those areas covered by mussel lines in Yaldad Bay is indicative that animals are being excluded from, and limited of, available space. Considering the narrow coastal area mostly used by Chilean dolphins (comprising depths between five and ten $\mathrm{m}$ ), more than $32 \%$ is covered by mussel farming. This has a severe impact since it appears to be restricting access to a substantial portion of coastal waters potentially important for essential behaviours.

Salmon and mussel farm industries have several impacts in common. The considerable increase of boat traffic has caused significant shifts in Chilean dolphin behaviour (Ribeiro et al., 2005), and could eventually cause fatal collisions or area abandonment. Finally, water column and sediment eutrophication, altering species composition and diversity (Naylor et al., 2000), might also be reflected along the entire food web, producing declines in available food and decreasing habitat quality also for top predators.

Chilean dolphins in the study area displayed a restricted pattern of habitat use, especially to perform essential behaviours such as food-related activities. The habitat alterations due to aquaculture activities are likely to affect dolphin populations. It is fundamental to consider habitat use and movement patterns of these animals, at different spatio-temporal scales, when formulating regulations for aquaculture activities and adequate conservation policies and coastal ecosystem management that warrant the conservation of this species.

We extend our sincere gratitude to Stefan Bräger and Sonja Heinrich for their essential support. Universidad Austral de Chile provided accommodation throughout our study period. We are 
also thankful to all volunteers who helped in data collection: Alejandra Henny, Carla Christie, Carlos Lara, Gonzalo Burgos, Juan Harries, Nicolás Sanchez, Robert Ronconi, Ruth Ipa, Sarah Wong and Victor Castillo. Stefan Bräger, Rodrigo Hucke-Gaete, Daniza Molina, Sonja Heinrich and two anonymous referees provided valuable comments and improved earlier versions of this manuscript. S.R. was supported by the postgraduate programme in Ecology of the Universidade Federal do Rio Grande do Sul and a CNPq scholarship. This is contribution no. 6 of the Blue Whale Center (BWC/CBA, Chile).

\section{REFERENGES}

Bejder, L. \& Dawson, S., 2000. Abundancy, residency and habitat utilization of Hector's dolphins in Porpoise Bay, New Zealand. New Zealand Journal of Marine and Freshwater Research, 35, 277-287.

Bräger, S., Harraway, J.A. \& Manly, B.F.J., 2003. Habitat selection of a coastal dolphin species (Cephalorhynchus hectori). Marine Biology, 143, 233-244.

Buschmann, A.H., López, D.A. \& Medina, A., 1996. A review of the environmental effects and alternative production strategies of marine aquaculture in Chile. Aquatic Engineering, 15, 397-421.

Claude, M., Oporto, J.A., Ibáñez, C., Brieva, L., Espinosa P.C., \& Arqueros, W.M., 2000. La ineficiencia de la salmonicultura en Chile: aspectos sociales, económicos y ambientales. Santiago: Terram Publicaciones.

Goodall, R.N.P., 1994. Chilean dolphins Cephalorhynchus eutropia (Gray, 1846). In Handbook of marine mammals, vol. 5 (ed. S.H. Ridgway and S.R. Harrison), pp. 269-287. San Diego: Academic Press.

Heinrich, S., 2001. Behavioral ecology of Chilean dolphins around Southern Isla Chiloé, Chile. In Abstracts of the fourteenth Biennial Conference on the Biology of Marine Mammals of the Society for Marine Mammalogy, Vancouver, Canada, 28 November-3 December 2001, p. 96. Vancouver: Society for Marine Mammalogy.

IUCN, 2004. 2004 IUCN red list of threatened species. http://www. redlist.org

Karczmarski, L., Cockcroft, V.G. \& McLachlan, A., 2000. Habitat use and preference of indo-pacific humpback dolphins Sousa chinensis in Algoa Bay, South Africa. Marine Mammal Science, 16, 65-79.

Kemper, C.M., Pemberton, D., Cawthorn, M., Heinrich, S., Mann, J., Würsig, B., Shaughnessey, P. \& Gales, R., 2003. Aquaculture and marine mammals: co-existence or conflict? In Marine mammals: fisheries, tourism and management issues ( ed. N. Gales et al.), pp. 208-225. Collingwood: CSIRO Publishing.
Lescrauwaet, A.C., Gibbons, J., Guzman, L. \& Schiavini, A., 2000. Abundance estimation of Commerson's dolphin in the eastern area of the Strait of Magellan, Chile. Revista Chilena de Historia Natural, 73, 473-478.

Mann, J., 1999a. Behavioral sampling methods for cetacean: a review and critique. Marine Mammal Science, 15, 102-122.

Mann, J., 1999b. Report on recent changes in female dolphin ranging in Red Cliff Bay, off Monkey Mia, Shark Bay. West Australian Department of Fisheries and West Australian Department of Conservation and Land Management, Perth.

Mann, J. \& Janik, V.M., 1999. Preliminary report on dolphin habitat use in relation to oyster farm activities in Red Cliff Bay, Shark Bay. West Australian Department of Fisheries and West Australian Department of Conservation and Land Management, Perth.

Mann, K.M. \& Lazier, J.R.N., 1991. Dynamics of marine ecosystems. Massachusetts: Blackwell Scientific Publications.

Naylor, R.L. et al., 2000. Effects of aquaculture on world fish supplies. Nature, London, 405, 1017-1024.

Ribeiro, S., Viddi, F.A. \& Freitas, T.R.O., 2005. Behavioural responses by Chilean dolphins (Cephalorhynchus eutropia) to boats in Yaldad Bay, southern Chile. Aquatic Mammals, 31, 234-242.

Stevick, P.T., McConnel, B.J. \& Hammond, P.S., 2002. Patterns of movement. In Marine mammal biology: an evolutionary approach (ed. A.R. Hoelzel), pp. 185-216. Oxford: Blackwell Science.

Winter, J., Navarro, J.M., Román, C. \& Chaparro, O., 1982. Programa de explotación de Mitilideos. Investigación Científica Básica: 2a parte. Technical Report AP 81/39, Corporación de Fomento de la Producción, Valdivia.

Würsig, B., Cipriano, F. \& Würsig, M., 1991. Dolphins movement and patterns. Information from radio and theodolite tracking studies. In Dolphins societies: discoveries and puzzles (ed. K. Pryor and K. Norris), pp. 79-112. Los Angeles: University of California Press.

Würsig, B. \& Gailey, G.A., 2002. Marine mammals and aquaculture: conflicts and potential resolutions. In Responsible marine aquaculture (ed. R.R. Stickney and J.P. McVey), pp. 45-59. Wellington: CAB International.

Submitted 20 Fuly 2005. Accepted 15 May 2006. 